UDK $72.011 \quad$ doi: 10.31650/2519-4208-2020-20-296-306

\title{
ART IN THE ERA OF CHANGE AND CHANGE IN ART
}

Gerasimova L. D., Associate Professor, Head of the Department of Fine Arts Odesa state academy of building and architecture. Ukraine

Tel. (048)702-14-59

Sapunova M. Yu., S. arch., associate professor of the Department of Fine Arts Odesa state academy of building and architecture. Ukraine

Tel. (097)340-92-87

Rahubenko G. L., Assistant of the Department of Fine Arts

Odesa State Academy of Civil Engineering and Architecture. Ukraine

Tel. +380672819360

Abstract: The article examines and analyzes the changes in the world of culture and art that have involved the postmodernism era, which arose during a period of rapidly changing moods in society, which accept the appearance of culture, but are absolutely alien and ugly, bearing the decline and destruction. Art, which is a kind of mark of the epoch and a reflection of morality, established stereotypes, and lifestyle, has experienced many revolutionary trends caused by the demand of a particular time period. In modern culture, there is a negative trend in the development of artistic, literary, and cinematic production, everything is oriented to the market needs. Canons are being collapsed, content is being simplified, and technologies are being violated. Culture and art began to meet individual human needs, acquired a commercial character and became subject to the influence of the customer and the consumer.

What is a "mass" culture? How much does the understanding of art depend on a person's wealth and education? For whom is culture now intelligible? How does the society standard of living influence culture and art in general?

Key words: Modern art, artistic value, conceptual art, idea, masterpiece, culture, taste, painting, artist, cultural heritage, artistic education.

\section{МИСТЕЦТВО В ЕПОХУ ЗМІН ТА ЗМІНИ У МИСТЕЦТВІ}

Герасімова Д. Л., доцент, завідуюча кафедрою образотворчого мистецтва Одеська державна академія будівниитва і архітектури. Україна Тел. (048) 702-14-59

Сапунова М. Ю., к. арх., доцент кафедри образотворчого мистецтва Одеська державна академія будівництва і архітектури. Україна Тел. (097)340-92-87

Рахубенко Г. Л., асистент кафедри Образотворчого мистецтва Одеська державна академія будівництва і архітектури. Україна. Тел. +380672819360

Анотація: У статті розглядаються й аналізуються зміни в світі культури і мистецтва, що охопили епоху постмодернізму, які виникли в період стрімко мінливих настроїв в суспільстві і мають зовнішність культури, але абсолютно чужі і потворні, що несуть занепад і руйнування. Мистецтво, що є своєрідною міткою епохи і відображенням моралі, усталених стереотипів, укладу життя, пережило багато революційних напрямів, викликаних вимогою того чи іншого часу. Сучасна культура, література, кінематограф все частіше орієнтується на запити ринку. Руйнуються канони, спрощується зміст, 
порушуються технології. Культура, мистецтво стали задовольняти ниці людські потреби, набули комерційного характеру і стали підвладні впливу замовника і споживача.

У мистецтві XX століття, що отримало назву «постмодернізм», починаючи з 60-х, відбувається перехід від зображення до вибудовування образу (інсталяції та перформанси), в основі цих явищ, концептуальне мистецтво. В цей же час з'являється протистояння «високого мистецтва» модернізму і зародження «масового». У період з 1960-х по 1980-ті роки активно зросла роль суспільства і соціальних процесів, що впливають на зображувані об'єкти. У сучасному мистецтві зображувальність стає не головним або майже зникає.

Кожен етап в історії супроводжувався виникненням характерних для нього технологій, стилів і канонів зображення, моральних норм і т. д. У кожному періоді мистецтва $є$ принципові ціннісні і світоглядні позиції, за якими можна трактувати приналежність певного часового витка, що відбиваються в першу чергу в сюжеті, композиції, стилістиці, колірному i тоновому вирішенні, що характеризуються використанням всіх попередніх досягнень. На сучасне мистецтво величезний вплив справили появи нових комп'ютерних, відео- та аудіотехнологій, що призвело до вибуху норм і порушило існуючі правила формування технологічного процесу. Суть мистецтва, що виникло в XX столітті, це еволюція, яка зачепила кілька століть заперечення академічного консерватизму, пошук альтернативних нових виразних засобів. До всього цього ринкова економіка внесла свої корективи. Цінності матеріальні стали переважати над духовними. I як тепер дати оцінку художньої цінності твору, кому оцінювати і за якими критеріями?

Оцінка твори мистецтва, будь то архітектура, література, музика або художній твір, багато в чому залежить від того, хто оцінює. Оцінює фахівець або обиватель, кожен керується своїми знаннями і власним досвідом, а так само своїми пристрастями. Що стосується художньої, моральної і духовної оцінки твору, на наш погляд, з усіх наведених критеріїв можна вибрати універсальний підхід до оцінювання твору, який відображає таблиця (таб.1).

Що є «масова» культура, наскільки залежить розуміння мистецтва від достатку і освіти людини? Було проведено опитування людей без освіти і таких, що мають освіту, щодо критеріїв оцінювання художнього твору, щоб визначити, чи має вплив освіта i достаток. Якщо в першому випадку оцінки фахівців практично перетинаються з думкою опитаних, то в другому випадку ми маємо оцінку так званого «масового» мистецтва, спрямованого на задоволення потреб суспільства. 3 чого випливає висновок, що те, що відбувається в нашому суспільстві, зміна свідомості диктується відсутністю або низькою якістю освіти опитуваних. Освіта і матеріальний достаток лежать в основі успішного розвитку суспільства. Саме освіта в подальшому дає можливість отримувати стабільний дохід, а дохід дає змогу здобути освіту. В результаті виникає пряма залежність якості сучасного мистецтва від добробуту і освіти суспільства. На жаль, в Україні різко скорочується кількість вузів, за рейтингом рівня освіти Україна знаходиться на 46 місці зі 189. За минулі десятиліття якості освіти не надавалася належна увага, фінансові потоки вливалися в світ мистецтва, змінюючи усталені правила i канони. В результаті формуються масові культури, викликані комерційним підходом, з пагубним впливом на підлітків. Так звана «кліпова культура» породила «кліпове мислення», яке фундаментально змінює характер сприйняття інформації: у школярів падає інтерес до навчання, пошуку і формування логічних зв'язків, відпадає необхідність самоаналізу. Діти акцентують увагу тільки на зовнішніх, поверхневих ознаках, не вникаючи в суть проблеми. Для людини з кліповим мисленням складно провести історичний аналіз, тому що пам'ять його короткочасна і не здатна зберігати інформацію тривалий час, що істотно позначається в їі оцінці того, що відбувається. Цей факт дозволяє з легкістю маніпулювати думкою і свідомістю. I культура, якою маніпулюють в своїх цілях, використовуючи 
мистецтво як бізнес, перетворює іiі в потворність, де немає художньої гідності, немає самої картини як предмета художнього мистецтва.

Таким чином, в умовах стрімкої глобалізації одна $з$ насущних проблем - активне зростання масової культури нового покоління, а значить і необхідність забезпечити прихід професіоналів, що володіють необхідними широкими знаннями в поєднанні з потребами суспільства.

Ключові слова: сучасне мистецтво, художня цінність, концептуальне мистецтво, ідея, шедевр, культура, смак, живопис, художник, творчість, культурна спадщина, художня освіта.

\section{ИСКУССТВО В ЭПОХУ ПЕРЕМЕН И ПЕРЕМЕНЫ В ИСКУССТВЕ}

Герасимова Д. Л., доцент, заведующая кафедрой изобразительного искусства Одесская государственная академия строительства и архитектуры. Украина Тел. (048)702-14-59

СапуноваМ. Ю., к. арх, доцент кафедры изобразительного искусства

Одесская государственная академия строительства и архитектуры. Украина Тел. (097)340-92-87

Рахубенко Г. Л., асистент кафедры изобразительного искусства Одесская государственная академия строительства и архитектуры. Украина Тел. +380672819360

Аннотация: В статье рассматриваются и анализируются изменения в мире культуры и искусства, охватившие эпоху постмодернизма, возникшие в период стремительно меняющихся настроений в обществе, принимающие внешность культуры, но абсолютно чуждые и уродливые, несущие упадок и разрушение. Искусство, являющееся своеобразной меткой эпохи и отражением морали, устоявшихся стереотипов, уклада жизни, пережило много революционных направлений, вызванных требованием того или иного временного периода. В современной культуре наблюдается тенденция развития художественного, литературного, кинематографического производства, где все ориентируется на запросы рынка. Рушатся каноны, упрощается содержание, нарушаются технологии. Культура, искусство стали удовлетворять низменные человеческие потребности, обрели коммерческий характер и стали подвластны влиянию заказчика и потребителя.

В искусстве XX века, получившем название «постмодернизм», начиная с 60-х, происходит переход от изображения к выстраиванию образа (инсталляции и перфомансы), в основе этих явлений лежит концептуальное искусство. В это же время появляется противостояние «высокому искусству» модернизма и зарождение «массового». В период с 1960-х по 1980-е годы активно возросла роль общества и социальных процессов, влияющих на изображаемые объекты. В современном искусстве изобразительность становится не главным или почти исчезает.

Каждый этап в истории сопровождался возникновением характерных для него технологий, стилей и канонов изображения, моральных норм и т. д. В каждом периоде искусства есть принципиальные ценностные и мировоззренческие позиции, по которым можно трактовать принадлежность определенному временному витку, отражающиеся в первую очередь в сюжете, композиции, стилистике, цветовом и тоновом решении, характеризующиеся использованием всех предыдущих достижений. На современное искусство огромное влияние оказало появление новых компьютерных, видео- и аудиотехнологий, что привело к взрыву норм и нарушило существующие правила формирования технологического процесса. Суть искусства, возникшего в XX веке, это эволюция, затронувшая несколько веков отрицания академического консерватизма, поиска 
альтернативных новых выразительных средств. Ко всему этому рыночная экономика внесла свои корректировки. Ценности материальные стали преобладать над духовными. И как теперь дать оценку художественной ценности произведения, кому оценивать и по каким критериям? Оценка произведения искусства, будь то архитектура, литература, музыка или художественное произведение, во многом зависит от того, кто оценивает. Оценивает специалист или обыватель, каждый руководствуется своими познаниями и собственным опытом, а также своими пристрастиями. Что касается художественной, моральной и духовной оценки произведения, на наш взгляд, из всех приведенных критериев можно выбрать универсальный подход к оцениванию произведения, который отображает приведенная таблица (таб.1).

Что есть «массовая» культура, насколько зависит понимание искусства от достатка и образования человека? Был проведен опрос людей без образования и имеющих образование относительно критериев оценивания художественного произведения, чтобы определить, имеет ли влияние образование и достаток. Если в первом случае оценки специалистов практически пересекаются с мнением опрошенных, то во втором случае мы имеем оценку так называемого «массового» искусства, направленного на удовлетворение потребностей общества. Из чего следует вывод, что происходящее в нашем обществе изменение сознания диктуется отсутствием или низким качеством образования опрашиваемых.

Образование и материальный достаток лежат в основе успешно развивающегося общества. Именно образование в дальнейшем дает возможность получать стабильный доход, а доход позволяет получить образование. В результате возникает прямая зависимость качества современного искусства от благосостояния и образования общества.

К сожалению, в Украине резко сокращается количество вузов, по рейтингу уровня образования Украина находится на 46 месте из 189. За минувшие десятилетия качеству образования не оказывалось должного внимания, финансовые потоки вливались в мир искусства, отрицая устоявшиеся правила и каноны. В результате формируются массовые культуры, вызванные коммерческим подходом, с пагубным влиянием на подростков. Так называемая «клиповая культура» породила «клиповое мышление», которое фундаментально изменяет характер восприятия информации: у школьников падает интерес к учебе, поиску и формированию логических связей, отпадает необходимость самоанализа. Дети акцентируют внимание только на внешних поверхностных признаках, не вникая в суть проблемы. Для человека с клиповым мышлением сложно провести исторический анализ, т. к. память его кратковременна и не способна хранить информацию длительное время, что существенно сказывается в его оценке происходящего. Этот факт позволяет с легкостью манипулировать мнением и сознанием. И культура, которой манипулируют в своих целях, используя искусство как бизнес, превращает его в уродство, где нет художественного достоинства, нет самой картины как предмета художественного искусства.

Таким образом, в условиях стремительной глобализации одна из насущных проблем - активный рост массовой культуры нового поколения, а значит и необходимость обеспечить приход профессионалов, обладающих необходимыми широкими знаниями в сочетании с потребностями общества.

Ключевые слова: современное искусство, художественная ценность, концептуальное искусство, идея, шедевр, культура, вкус, живопись, художник, творчество, культурное наследие, художественное образование. 
You're so ugly you could be a modern art masterpiece! Stanley Kubrick

Problem statement. Can we say that modern culture and art have absorbed and fulfilled themselves in new forms of creative expression, reflecting the main development milestones from the Romanesque style to postmodernism? Many experts consider that time is the main factor for understanding and accepting contemporary art, and only a true masterpiece will pass the test of centuries-old censorship. How can we understand what is true and what is not? What is the essence of art?

The process of contemplation and cognition of a piece of art is always accompanied by a psychological impact on the person, as a result of which emotions and understanding arise.

The birth of mass culture began in the 19th century in France, but in the modern art of the world society, it is a parasitic disease that makes art meaningless, it loses the unity of form and content, integrity, artistic truth, the psychological impact of a piece of art on the viewer is limited to shock and shocking behavior. "Shocking behavior is a deliberately provocative act or provocative, shocking behavior that contradicts the legal, moral, social and other norms accepted in society and is demonstrated in order to attract attention"[2]. This raises the question of what information this piece of art is able to convey to future generations, and what is its price in the age-century history.

Analysis of recent researches and publications. In the art of the 20th century, called "postmodernism", there is a shift from figure to image-building (installations and performances) since the 60s, it was based on conceptual art. At the same time, the opposition to the high art of modernism and the birth of "popular art" appears. In the period from 1960 to 80-ies, the role of society and social processes in the imaging objects extensively increased. In comparison, the image becomes not the main thing or almost disappears in modern art. The viewer is no longer important, but the artist's self-expression is important. All means are good here, mad tricks, bold proposals and deep philosophical ideas. This has affected literature, architecture, fine arts, cinema, etc. Many philosophers and artists have tried to assess the importance of art and its role in the formation of spiritual society, to assess the creator's skill and his work. Yu. V. Matskevich [7], the literary critic Mikhalchenko B. S. [9], Volobuiev O. V., Pesotskyi V. A. [1], Kiyashchenko N. I. [5], Stolovich L. N. [10] and others applied to this issue.

Object and purpose of the article. To distinguish art from a commercial project and protect yourself from pseudo-art, actively imposed by the general cultural level of modern society. To determine what caused the demand for popular art, to form the parameters and criteria of art evaluation.

For many centuries, culture and art have been a reflection of both the best and worst aspects of society. The art satirised, actualized and extolled many things. This proves that the culture was creative, instructive and analytical, had clear norms and directions. However, the defining function of culture is the humanistic, educational, and spiritual and moral position.

Each stage in history was accompanied by the emergence of its characteristic technologies, styles and canons of image, moral norms, etc. The world art history has collected and highlighted all the artistic value of the works of past eras. Each period of art has fundamental values and worldviews, which can be interpreted as belonging to a certain time cycle, reflected primarily in the plot, composition, style, color and tone solutions, etc., characterized by the use of all previous achievements. This is associated with the transfer of spiritual, cultural, material, political and technological heritage.

Modern culture did not escape changes. The monetization of modern art has absorbed all the cultural manifestations inherent in modern society. In order to become familiar with art that 
does not have criteria and canons, it is necessary to refer to the time frame and the main representatives whose work represents this stage, as well as to understand the moods and values of the society of this period.

Modern art has been greatly influenced by the emergence of new computer, video and audio technologies, which led to norms explosion and violated the existing rules for the technological process formation. There was a conflict between established canons and society modern requirements. At this stage information technologies form the basis of modern civilization and the saturation of technological processes requires the maximum increase in the culture level and education in society, which we would like to turn attention to.

The most famous masterpieces always appear in the revolutions period, at the turn of new epochs, at the moment of searching for new art. The essence of art that emerged in the 20th century is an evolution that affected several centuries of academic conservatism denial, the search for alternative new means of expression. The changes affected not only the attitude to art, but also technological processes. But even so, each era fought for its own ideas and values. And as a result of many years of struggle for freedom and an independent view there is the rejection of spiritual content and realistic images. The market economy has made adjustments to all of this. Material values began to prevail over spiritual values. "Values [ ...] play an important role in the development of society as regulators of people's behavior, as "accumulators" of human culture" [10, p. 8-9].

Mass culture can be considered as a kind of opposition to academic culture, the platform of which is based on the fact that academic education is aimed at the dedicated, culturally educated people, but popular art is intended for all segments of society. "Evaluation is an act of value awareness. At the same time, if the artistic value that arises in the process of public artistic practice is by its nature objective, then the artistic evaluation is subjective. The latter is based on the interests and artistic needs of a particular cultural and historical subject. It is formed by value requirements that form a historically mobile and complex hierarchical system. Moreover, artistic evaluation always carries an emotional, sensual shade - as if reflecting the experienced feelings, which is then transferred to the intellectual level" [6, p. 187].

It is possible to estimate the artistic value with a foundation of some basic components, certain characteristics, and a unique methodology that has been proposed by art historians, philosophers, literary critics, and experts who can determine the value of a piece of art based on the culture history knowledge, as well as objectively assess the semantic content of new directions. The evaluation of a piece of art, whether it is architecture, literature, music, or a fictional work, depends largely on who evaluates it. Whether it is assessed by a specialist or an average citizen, each is guided by their knowledge and their own experience, as well as their preferences. "The person does not derive the knowledge content from his or her own depths. It is involuntary depends on the reality itself, so knowledge and mental activity of a person and society is a process of reflection of this reality in consciousness" [1, p. 10]. The artistic evaluation subjectivity has an objective, universal character, and therefore is especially openly manifested in non-professional judgments about art. In relation to literature, for example, L. Vyhotskyi considered such "readers' " criticism as openly subjective and of no importance [6].

The works of Yu.V. Matskevich and A.S. Zhantaiev, N.I. Kiyashchenko, Mikhalchenko B. S., the specialists' opinion of the Department of Fine Arts of OGAS in the field of art, literature and art history such as Professor A. A. Horbenko, Associate Professor Yu. P. Valiuk were studied and analyzed. We determined the most important and universal criteria for evaluating the piece of art value of each period, allowing us to call it a masterpiece (Tab.1). As for the work evaluation, in our opinion, we can choose a universal approach to the evaluation of the work from all the above criteria. This table helps cover art trends and their meaning, and give 
a description of the most important criteria for evaluating works of art in our opinion: plot, ideology, practical value, etc.

At the same time, 100 people who were related to culture and art and did not have special education were interviewed during the experiment. All of them were asked one question: "Determine for yourself what criteria will you use to evaluate the piece of work you would like to purchase?". Among the 100 people surveyed, 50\% had higher education, 30\% had secondary education, and $20 \%$ had no education at all. We divided the opinions of people without education and those with education in the survey.

\section{Art Evaluation Criteria}

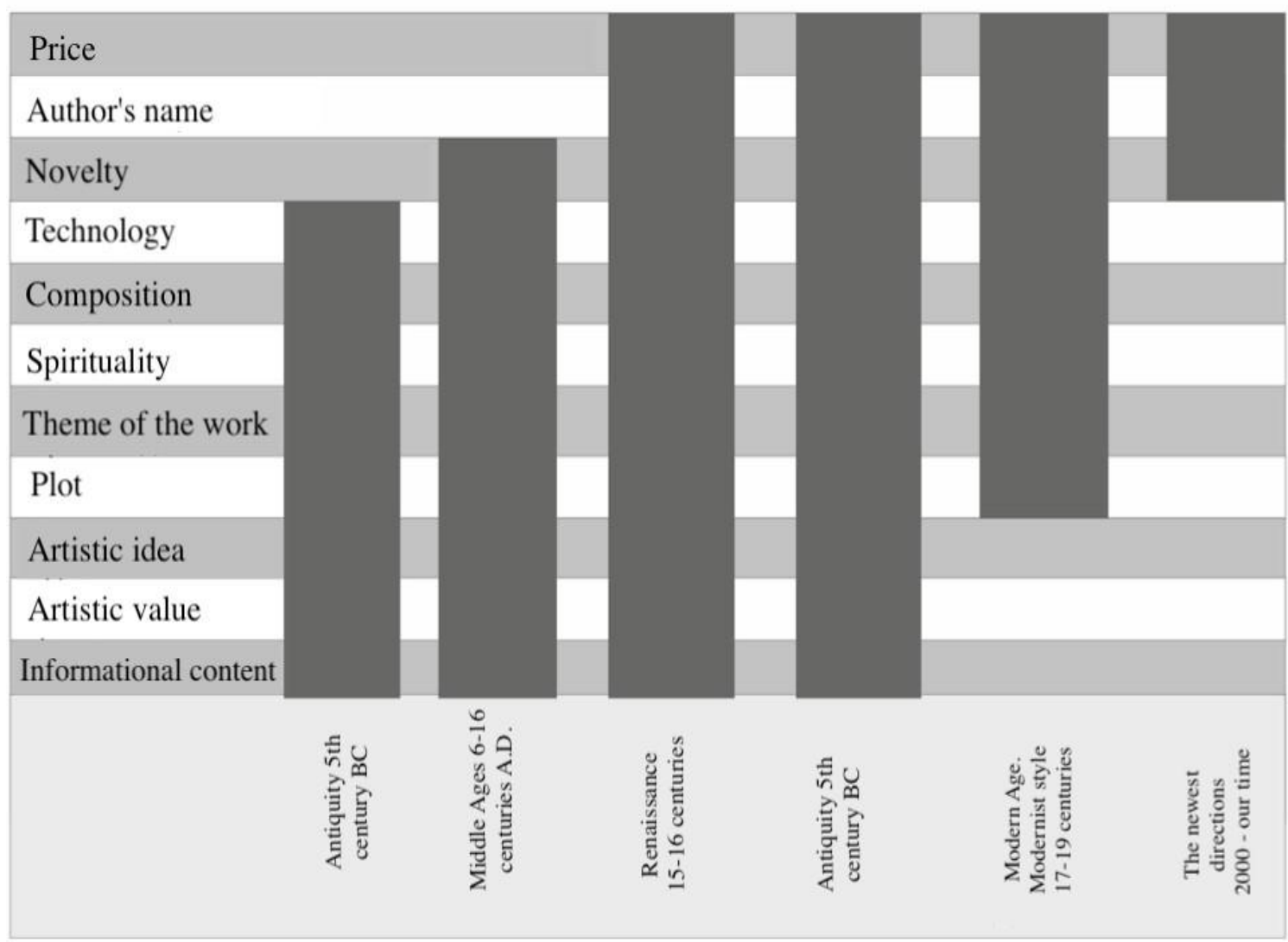

During the survey among the inhabitants of the city of Odesa, the following indicators were formed, which are most often used in determining the art evaluation criteria. This was a personal opinion of the respondents, among whom $60 \%$ had artistic education, $20 \%$ had higher education and $20 \%$ had secondary special education, but not in art.

The placement order of evaluation criteria by the number of repetitions:

1. informational content for education;

2. time-tested art that is not subject to fashion trends;

3. does not have negative messages;

4. the author's popularity;

5. there is no desire to copy or reproduce;

6 has an energy potential;

7. has a great material value, or is priceless. 
And here is the data among $100 \%$ of the respondents who have no education and are not related to art:

1. the reason to purchase;

2. the realistic image;

3. the author's popularity;

4. the genre is important;

5. the material value;

6. it is bright, colored;

7. the size;

8. like it or not;

9. it fits the interior.

If in the first case, the experts assessments practically cross with the respondent's opinion, in the second case, we have an assessment of the so-called "popular" art aimed at meeting the society needs. And the "masses" is known to think in stereotypes. The meaning loss at the level of thinking by stereotypes makes impossible an individual, independent vision that requires intellectual effort. "Popular culture is not actually a culture for the masses, nor is it a culture of the masses that they create and consume. This is the part of culture that is created, but not made by the masses themselves. It is created by order and under pressure from the dominant forces in economics, ideology, politics, the sphere of legal and even moral relations. Because of this fact, the mass culture has been created by the masses since the beginning of the social differentiation of society into its different groups, strata, or classes. Name the results of this differentiation as you like" [5, p. 54].

This leads to the conclusion that the consciousness change occurring in our society is dictated by the lack or low quality of higher education of the respondents. Consequently, the as yet opinion of the minority is becoming aggressive and important, in the understanding that today the number of universities is sharply reduced in Ukraine. In 2019, the number of Universities decreased by 3\%. This trend is disappointing, since Ukraine ranks 46th out of 189 in the education rating, including Niger, Chad and South Sudan. The Education Index is a combined indicator of the United Nations Development Programme (UNDP). It is one of the key indicators of social development. When determining a place in the world ranking, all countries are ranked based on the Education Index. Data on literacy is derived from official results of national population censuses and compared with indicators calculated by the UNESCO Institute of Statistics. It is considered that developed countries should have a minimum indicator of 0.8 [13]. Ukraine has 0.797 (Tab.2).

Table 2

\begin{tabular}{|c|c|c|}
\hline \multicolumn{3}{|c|}{ RANKING OF WORLD COUNTRIES BY EDUCATION INDEX } \\
\hline 44 & Luxembourg & 0.802 \\
\hline 45 & Montenegro & 0.798 \\
\hline 46 & Ukraine & 0.797 \\
\hline 47 & Croatia & 0.796 \\
\hline
\end{tabular}

At the current time, the criteria for popularity and values of "popular" art are reduced to how much the author is in demand, relevant, on-trend and purchased, promoted and recognized, 
and not what semantic, aesthetic and moral value the work carries. To form an analytical understanding and to give an effective assessment of the piece of art is possible having some knowledge gained in the process of learning, information accumulation and financial independence. Education and material wealth are the basis of a successfully developing society. Not many people understand the ability of education to influence and thereby change society. It is education that makes it possible to get a stable income in the future, and income allows you to get an education. As a result, there is a direct dependence of the modern art quality on the welfare and education of society.

The number of cultures in art that appeared during the new time and the new direction (Tab. 1), grows in arithmetic progression. Reinforcing each other and mixing the previous ones, they sweep away everything before them that once had value and sense. "Money played an important role here. Over the past decades, a huge amount of filthy lucre has been invested in the art world. Public money was spent generously in the "improvement" of old museums and creating new ones. The communism collapse and the rejection of state intervention in the market economy (and as a result - globalization) led to an increase in the multi-millionaires population, who considered the purchase of modern art as a very profitable investment" [2, p. 11].

The harmful influence of this culture can be estimated by the most popular and modern, so-called clip culture, which combines commercial cinema and advertising means. The emergence of "clip consciousness "as a new cultural phenomenon typical of the information age was discussed in the 1960s, and in the 1990s its product was" clip thinking " in adolescents. In 2010, A. Toffler, an American futurologist, describes clip thinking as an organism protective reaction to an abundance of information of different kinds. Clip thinking is a term of recent decades that describes the way information is perceived by the new generation and is characterized by a superficial content perception. "Mostly, representatives of the younger generation - students and schoolchildren - possess clip thinking. Many teachers note fundamental changes in the way information is perceived: schoolchildren's interest in learning, searching for and forming logical connections decreases, and there is no need for self-analysis. Most students are not adapted to serious cognitive work, it is increasingly difficult for them to read long literary works, many do not cope with writing statements, because they simply cannot understand the structure of the narration and highlight the general idea of the work. Children focus only on external surface features, without delving into the problem essence. Owners of clip consciousness lose the ability to differentiate junk and useful information and consume simpler information in form and content" [4, p. 172]. This opens up a wide range of possibilities for mind control. The usual way for a person with clip thinking to perceive information does not allow forming semantic connections between phenomena and leads to consciousness fragmentation. Mind control occurs not only in the political sphere, but also in the economic, social and cultural spheres, acquiring a social character. For a person with clip thinking, it is difficult to conduct a historical analysis, because his/her memory is short-lived and is not able to store information for a long time, which significantly affects his/her assessment of what is happening. "The clip, like leprosy, is attacking all traditional forms of art today, it is beginning to penetrate even in literature, theater and opera and ballet. Instant flickering of something similar to pictures, shots, musical sounds and primitive rhythms, plastic with obligatory sexual and erotic elements-these are the main set of means of the clip culture expression and tools of writers and directors of this type of modern cinema. This is a natural development of mass cinema in its flow, serial manifestation. A special place in the terminological baggage of future teachers can and should take such terms as" mass", "commercialized"," flow " production of spiritual values, objects and ways of entertainment and distraction from the serious problems of human life. This is where a very important cultural point arises: are the concepts "mass of the people", "mass of producers", "mass of consumers" and mass in culture and art identical in general? This question arose by itself, as soon as in the XVIII century Goethe and Schiller first used the term "mass culture and 
popular art", and then in the XIX century Nietzsche, after a long strong friendship with Wagner and adoration of his music, began to accuse his friend that he was beginning to pander to the mass taste in music, began to create for the needs of the public, satisfied with standard musical solutions, plot moves and familiar musical consonances" [5, p. 49].

Culture, which is manipulated for its own purposes, using art as a business, turns it into an ugliness, with no artistic dignity, with no picture itself as an art object, with worship of the "god of money" and only profit matters, with demolished monuments and burned books. All this is the first sign of decline in society. "In fact, from the first to the last, from the small to the great - for all of us, the fall of consciousness and literature may be less noticeable, but no less real and terrible disaster than war, diseases and famine" [8, p. 3].

Pseudo-art, which is created for the purpose of earning money, reflects the needs and fulfills the requests of a certain small part of society, which does not make any effort to understand, and in most cases does not understand the historical cultural processes, imposing its point of view on everyone around it. The ugliness of architecture, which spoils the city appearance, raises skyscrapers in low-rise Odesa and hanging plastic balconies on historical buildings, literature and cinema, praising the power as the only means of combating lawlessness, a successful person in a "nice package", is only a small part of the problem that already hangs over society. From generation to generation, the boundaries of what is permitted will be erased, and new ones will be formed, but not time-tested ones, but those that have arisen for the needs of society. "No one would remember how the idea that an artist should be hungry was formed, that it was material need that pushed a talented person to a desperate search for inspiration, while security and well-being were connected with a gradual mental obesity and, as a result, an unwillingness to create" [11, p. 5].

"Art is in decline!»». And in fact, we are all in crisis and decline, which art faithfully reflects. And in order not to fall into a social depression, people surround themselves with kitsch - low-grade mass products that differ in the usual form, primitive content, designed for mass taste and glossy products, thus creating a certain mass of the viewer of fashion trends. As a result, society will decide what is valuable and what is junk, turning art into "mass culture".

Conclusions: In the context of rapid globalization, one of the vital problems is the active growth of mass culture of the new generation, and therefore the need to ensure the arrival of professionals with the necessary widespread knowledge in combination with the needs of society. We need an objective view of the preservation of universal moral ideals as an integral part of the maintenance and further development of a morally healthy society and cultural values, so that the development level of material culture does not lead to the spiritual culture degradation.

\section{LITERATURE}

1. Volobuiev O.V.,Pesotskyi V.A. The problem of the fiction book quality assessing (sociophilosophical aspect). Bulletin of Moscow Region State University. Philosophical sciences series. Problema otsenki kachestva proizvedeniya khudozhestvennoy literatury (sotsial'no-filosofskiy aspekt) №1- 2013, pp.10-20. (In Russian)

2. Vlasov V.H., Lukina N.Yu. Avant-gardism. Modernism. Postmodernism: A Terminological Dictionary. St. Petersburg, 2005, p.309. (In Russian)

3. Gompertz W. WHAT ARE YOU LOOKING AT? 150 Years of Modern Art in the Blink of an Eye (Translation from English by Litvinova I.) Moscow: Sinbad, 2016, pp.464. (In Russian)

4. Dokuka S.V. Clip Thinking as a Phenomenon of the Information Society // Social Sciences and Modernity. Klipovoe myshlenie kak fenomen informacionnogo obshhestva. Obshhestvennye nauki i sovremennost'.Vol. 2/2013(In Russian) 
5. Kiyashchenko N.I. Mass culture and mass art as a global problem of the XXI century / Philosophy and society. Vol. 4 (33) Massovaya kultura i massovoye iskusstvo kak global'naya problema XXI veka / Filosofiya i obshchestvo. Vol.3(33)/ 2003. (In Russian)

6. Kurysheva T. A. Musical journalism and music criticism: a study guide for universities. Muzykalnaya zhurnalistika i muzykal'naya kritika. Vlados-press Publ., 2007, 295 p. (In Russian)

7. Matskevich. Yu.V. The definition of the concept of " piece of art "and the designation of the criteria for its evaluation". Opredeleniye ponyatiya "proizvedeniye iskusstva» $i$ oboznachenii kriteriyev yego otsenki. (In Russian)

8. Merezhkovsky, D. S. On the decline reasons and the new trends of modern Russian literature / Eternal satellites. Portraits from world literature. O prichinakh upadka $i$ o novykh techeniyakh sovremennoy russkoy literatury / Vechnyye sputniki. Portrety iz vsemirnoy literatury. St. Petersburg, Science Publ, 2007, pp. 428-502. (In Russian)

9. Mikhalchenko B.S. Problems of literary criticism: a theory of literature. Problemy literaturovedeniya: teoriya literatury. (In Russian)

10. Stolovich L.N. The nature of aesthetic value. Priroda esteticheskoy tsennosti. Moscow, 1972, 272 p. (In Russian)

11. Sorokina N. Art and money. Iskusstvo i dengi. Moscow, AST Publ., 2016, 272 p. (In Russian)

12. Yakovleva A.M. Kitsch and Parakich: The Birth of Art from the Prose of Life // The Art Life of Russia in the 1970s as a Systemic Whole. Kich i parakich: Rozhdeniye iskusstva iz prozy zhizni // Khudozhestvennaya zhizn' Rossii 1970-kh godov kak sistemnoye tseloye. St. Petersburg: Aletheia Publ., 2001, pp. 252-263. (In Russian)

13. Rating of the world countries in terms of education. Humanitarian Encyclopedia: Research [Electronic Resource] // Center for Humanitarian Technologies, 2006-2020 (latest revision: 01/17/2020). URL: https://gtmarket.ru/ratings/education-index/education-index-info

\section{METHODOLOGY FOR DETERMINING MATURITY OF COMPOSITIONAL SKILLS IN ARCHITECTURE STUDENTS}

Grigoryeva V. B., Ph. D. in Education, Assistant Professor, Head of the Sub-Department of Drawing, Painting and Architectural Graphics

Tel. +380980481617

Spodeniuk S. I. Senior Teacher at the Sub-Department of Drawing, Painting and Architectural Graphics

Tel. +380961847062

Poronik E. G. Senior Teacher at the Sub-Department of Drawing, Painting and Architectural Graphics

Tel. +380506750875

Odessa State Academy of Civil Engineering and Architecture

Abstract. In methodological literature an architect's culture of depiction is artificially divided into two components: artistic component and design component. However, contemporary studies pay not enough attention to development of compositional thinking in students as an important factor for uniting the above components.

Compositional thinking manifests itself in compositional activity, which is a specific quality of cognitive activity in art. Compositional activity involves both intellectual (acts of 